DOI:

Оксана Рогульська, кандидат педагогічних наук, доцент кафедри практики іноземної мови та методики викладання Хмельницького національного університету

\title{
ДОЦІЛЬНІСТЬ ВИКОРИСТАННЯ МУЛЬТИМЕДІЙНИХ ТЕХНОЛОГІЙ У ПІДГОТОВЦІ МАЙБУТНІХ УЧИТЕЛІВ ІНОЗЕМНИХ МОВ
}

У статті досліджено доцільність використання мультимедійних технологій у підготовиі майбутніх учителів іноземної мови, які відкривають небачені досі перспективи у розв 'язанні важливих завдань та ведуть за собою перехід від традиційної схеми репродуктивної передачі знань до нової, креативної форми навчання. Доведено, щэо використання мультимедійних презентацій у підготовці майбутніх вчителів іноземної мови, зокрема на заняттях з іноземної мови, забезпечує функиію передачі інформаиії, а також отримання зворотного зв 'язку в процесі ї̈ сприйняття та засвоєння, оскільки інформачія, представлена в наочній формі, є найбільш доступною для сприйняття, засвоюється легше і швидше.

Ключові слова: інформаиійні технологій; мультимедійні технологїі; майбутні учителі іноземноїмови мультимедійні презентації.

Puc. 3. Лim. 9.

Oksana Rohulska, Ph.D.(Pedagogy), Associate Professor of the Foreign Language Practice and Teaching Methodology Department Khmelnytskiy National University

\section{FEASIBILITY OF MULTIMEDIA TECHNOLOGIES APPLICATION IN THE FUTURE FOREIGN LANGUAGE TEACHERS' TRAINING}

The article deals with the feasibility of multimedia technologies application in the future foreign language teachers' training. It is underlined that these technologies open up unprecedented perspectives in solving important tasks and lead to a transition from the traditional scheme of reproductive knowledge transfer to a new, creative form of teaching and learning. It is established that multimedia technologies in foreign language classes contribute to: the formation of reading skills, due to the use of the Internet materials of different complexity levels; improvement of listening skills with the help of authentic audio texts, songs, movie episodes; developing skills of dialogue and monologue speech, improving writing skills, enriching the vocabulary (both active and passive), which reflects a certain stage in the development of the culture, the social and political structure of society; enriching the students with cultural knowledge, including language etiquette and the culture and traditions peculiarities; improving grammar knowledge through online exercises and tests. It is proved that the multimedia presentations application in the future foreign language teachers' training, in particular in foreign language classes, provides the function of information transfer, as well as receiving feedback in the process of its perception and assimilation, since the information presented in visual form is the most accessible for perception. It is stated that the multimedia technologies application in the future foreign language teachers' training contributes to the intensification and enrichment of the educational process, induces a conscious perception of educational material, motivates and activates the student's educational activity, individualizes the process of a foreign language learning, diversifies the forms of classes, as well as contributes to the development of mental and the students' creative abilities, increases interest in learning and the level of proficiency in a foreign language.

Keywords: information technologies; multimedia technologies; future foreign language teachers; multimedia presentations.

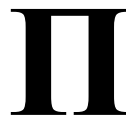

остановка проблеми. Соціальний та економічний розвиток країни вимагає забезпечення кваліфікованими кадрами, що здатні швидко адаптуватись до нових швидкоплинних умов сучасного життя та постійно оновлювати здобуті в закладах вищої освіти наукові знання. Нажаль нині традиційна система навчання в закладах вищої освіти не створює належних умов для ефективного розвитку розумових здібностей та творчих можливостей студентів, як результат суспільство одержує “пасивних" фахівців, які не готові до здійснення професійної діяльності в стрімких умовах інформатизації суспільства.

Слід зауважити, що традиційна система навчання має низку недоліків, серед яких: домінування словесних методів навчання, активність викладача і пасивність студента, орієнтованість навчальної програми на середнього студента, домінування навантаження на пам'ять студентів, представлення інформації в абстрактно-логічній формі; домінування 


\section{ДОЦІЛЬНСТЬ ВИКОРИСТАННЯМУЛЬТИМЕДІЙНИХ ТЕХНОЛОГЙ У ПЦДГОТОВЦІ МАЙБУТНІХ УЧИТЕЛІВ ІНОЗЕМНИХ МОВ}

репродуктивних методів навчання, усталена структура заняття, нераціональне використання часу на організацію продуктивної діяльності студентів, недостатнє використання інноваційних технологій навчання, інтерактивних методів, відсутність методичних та методологічних підходів та принципів, які б забезпечили формування цілісності й системності знань на заняттях тощо. Відтак майбутній фахівець не підготовлений до тих форм роботи, які зустрічаються у професійній діяльності, не здатний знаходити необхідну інформацію для певного виробничого рішення, та прийняти самостійне творче рішення в складних умовах.

Перераховані вище недоліки традиційної системи навчання складають серйозну проблему для освітнього процесу підготовки майбутніх учителів іноземної мови до професійної діяльності [7]. Зважаючи на вищезазначене, особливо нагальною є потреба в оновленні змістута підходів до фахової підготовки майбутнього вчителя іноземної мови у закладах вищої освіти України, перенесення уваги 3 процесу навчання на його результат, орієнтація змісту й організації навчання на сучасні методологічні підходи та принципи, урахування зарубіжного досвіду навчання іноземних мов, використання сучасних інноваційних, інтерактивних педагогічних технологій, новітніх методик, сучасних методів, форм та засобів навчання іноземних мов, що сприятимуть формуванню готовності майбутніх учителів іноземної мови до професійної діяльності.

Такі умови можуть бути створені за рахунок широкого використання сучасних інформаційних технологій, які відкривають небачені досі перспективи у розв'язанні важливих завдань та ведуть за собою перехід від традиційної схеми репродуктивної передачі знань до нової, креативної форми навчання.

Аналіз наукових джерел. У педагогічній науці приділяється належна увага проблемі впровадження інформаційних технологій у навчальний процес. Науковими дослідженнями щодо використання комп'ютерної техніки та нових інформаційних технологій в освіті займаються такі науковці, як В. Безпалько, В. Биков, А. Васюра, Б. Гершунський, Р. Гуревич, А. Єршов, М. Жалдак, М. Кадемія, Ю. Машбиць О. Майборода, В. Монахов, Н. Морзе, П. Піндера, О. Співаковський, П. Стефаненко, О. Філатов та ін.

Використання інформаційних технологій навчання у викладанні іноземних мов розглянуто у працях С. Азімова, С. Канатової, М. Кларіна, О.Крюкової,Л. Морської,Е. Носенко, О. Суховірського, Г. Селевка, та ін. Проблемами використання мультимедіа в освіті займались такі вчені як Н. Анісімова, С. Антонова, Я. Булахова, Т. Волошина, Н. Іщук, Т. Коваль, Н. Фролов, Л. Шевченко та ін.

Невирішена раніше частина проблеми. Не зважаючи на значну кількість наукових праць, в яких розглядається доцільність застосування інформаційних технологій в освіті, питанню використання мультимедійних технологій у підготовці майбутніх учителів іноземної мови приділено недостатньо уваги.

Мета статті - дослідити доцільність використання мультимедійних технологій у підготовці майбутніх учителів іноземної мови.

Виклад основного матеріалу. Як зазначає Ю. Буровицька, засоби інформаційних технологій наразі поділяються на апаратні засоби та програмне забезпечення. До апаратних засобів відносять персональний комп'ютер та його складові, локальні та глобальні мережі, сучасне периферійне обладнання, відеокамери, CD та DVD диски. Програмне забезпечення (програмні засоби) - це сукупність програм системи обробки інформації і програмних документів, необхідних для експлуатації цих програм. До них можна віднести Інтернет і його інструменти (електронна пошта, браузери, веб-сайти, пошукові системи, форуми, аудіо- та відео чати), засоби IР-телефонії, платформи для мережевих курсів, блоги, мікроблоги, сервіси для зберігання фото, відео, презентацій, контактні сервіси, smart-технології, хмарні технології, геосервіси [1].

А. Чурсіна стверджує, що комп’ютер (ноутбук, нетбук, планшетний пристрій, смартфон тощо), будучи технічною базою нових інформаційних технологій - це і засіб комунікації, і засіб оперативного отримання та обробки інформації, $\mathrm{i}$ засіб оновлення знань, і засіб набуття нових умінь. Відтак комп'ютер стає незамінним помічником викладача та студентів в опануванні інформаційними потоками, допомагає моделювати та ілюструвати процеси, явища, об'єкти, події, ідеї, думки, дослідження, висновки, комбінуючи текст і зображення, схеми, таблиці тощо. Розвиток та удосконалення комп'ютерних засобів дозволило широко використовувати в навчальномупроцесі мультимедійні технології, які в свою чергу, дозволяють інтегрувати різні середовища представлення інформації: текст, статичну і динамічну графіку, відео і аудіо записи в єдиний комплекс, що робить студента активним учасником навчального процесу, оскільки видача інформації відбувається у відповідь на його дії [2].

Застосування мультимедійних технологій у навчальному процесі сприяє: зростанню інформативності й репрезентативної цінності 


\section{ДОЦЛЬНІСТЬ ВИКОРИСТАННЯМУЛЬТИМЕДІЙНИХ ТЕХНОЛОПЙ У ПДГОТОВЦІ МАЙБУТНІХ УЧИТЕЛІВ ІНОЗЕМНИХ МОВ}

навчального матеріалу; стимулюванню когнітивних процесів (сприйняття й усвідомлення інформації), а отже, більш глибокому розумінню навчального матеріалу та систематизації набутих знань; розвитку розумових і творчих здібностей студентів; формуванню стійкої мотивації пізнавальної діяльності студентів на заняттях; розширенню меж самостійної діяльності студентів; урізноманітненню форм подання інформації та видів навчальних завдань; створенню навчального середовища, яке забезпечує “занурення” студента в уявний світ, у певні соціальні і виробничі ситуації; систематичному застосуванню ігрових прийомів; забезпеченню миттєвого зворотного зв'язку, можливість рефлексії; підвищенню рівня інформаційної культури студентів та рівня підготовки студентів у галузі сучасних інформаційних технологій; удосконаленню системи організації навчання на різних етапах заняття; розвитку в студентів навичок спільної роботи й колективного пізнання; створенню сприятливого психологічного клімату на занятті; можливості реалізації індивідуалізації навчання; підвищенню естетичного і емоціонального рівня заняття за рахунок використання музики, анімації тощо; підвищенню об'єму виконаної на занятті роботи.

Можливості мультимедійних засобів навчання, що використовуються на заняттях 3 іноземної мови невичерпні, вони сприяють: формуванню навичок і умінь читання, завдяки використанню матеріалів Інтернет-мережі різного рівня складності; вдосконаленню умінь аудіювання за рахунок використання аутентичних звукових текстів, пісень, кіно-епізодів; вдосконаленню умінь писемного мовлення, поповненню словникового запасу (як активного, так і пасивного) лексикою сучасної іноземної мови, яка відображує певний етап розвитку культури народу, соціальний i політичний устрій суспільства; збагаченню студентів культурологічними знаннями, які включають в себе мовленнєвий етикет та особливості культури та традицій країни, мова якої вивчається; вдосконаленню знань з граматики за допомогою виконання вправ та тестів у режимі online [6].

Використання мультимедійних презентацій у підготовці майбутніх вчителів іноземної мови, зокрема на заняттях з іноземної мови, забезпечує функцію передачі інформації, а також отримання зворотного зв'язку в процесі її сприйняття та засвоєння, оскільки інформація, представлена в наочній формі, є найбільш доступною для сприйняття, засвоюється легше і швидше. Відтак домінуюче місце на заняттях $з$ іноземної мови відводиться програмі Microsoft PowerPoint, що входить до складу офісного пакету Microsoft Office. Презентації, створені в PowerPoint, можна продемонструвати як на моніторі для невеликого кола осіб, так і на екрані за допомогою мультимедійного проектора. Вона надає можливість здійснювати віртуальну взаємодію користувача з об'єктами або процесами пізнання, які відображаються на екрані. Іншими словами, використання мультимедійних презентацій дозволяє створювати інформаційний і візуальний образ досліджуваного об'єкту. Принцип роботи даної програми полягає в послідовній демонстрації слайдів - окремих кадрів презентації, що містять різні елементи і способи форматування [9]. Кожний слайд може бути відображений на екрані, роздрукований на папері або прозорій плівці, наповнений текстовою та графічною інформацією, 3 можливістю використання мультимедійних компонентів (анімації, аудіо- та відео- файлів тощо) [4]. Відтак при демонстрації об'єкти можуть відразу відображатися на слайдах, а можуть з'являтися на них поступово, в певний час, визначений користувачем для підсилення наочності доповіді та акцентування на особливо важливих моментах iï змісту. За потреби користувач має можливість порушити визначену заздалегідь послідовність демонстрації слайдів і перейти до будь-якого з них в довільному порядку. Через гарячі точки користувачі можуть натиснути на гіперпосилання для переходу до інших слайдів, інших презентацій, або веб-сайтів. Відео та звук також можуть бути творчо вбудовані в слайдах [5].

Л. Гаврілова та І. Хижняк називають основні переваги презентаційного подання матеріалу:

- інформаційна ємність - можливість в одній презентації розмістити великий обсяг графічної, текстової, звукової інформації;

- компактність - для презентації можна використовувати різні типи сучасних носіїв, що вирізняються малим розміром і зручністю;

- емоційна привабливість - презентації надають можливість представити інформацію не лише в зручній для сприйняття послідовності, але й ефектно поєднувати звукові й візуальні образи, добирати домінантні кольори, що створюють у адресатів позитивне ставлення до інформації;

- наочність - презентація унаочнює, конкретизує чи обгрунтовує певні теоретичні положення;

- мобільність - загалом для презентації достатньо носія й комп'ютера, тобто вона може демонструватися в різних умовах; 


\section{ДОЦІЛЬНСТЬ ВИКОРИСТАННЯМУЛЬТИМЕДІЙНИХ ТЕХНОЛОГЙ У ПДГОТОВЦ МАЙБУТНІХ УЧИТЕЛІВ ІНОЗЕМНИХ МОВ}

- інтерактивність - можливість безпосередньо впливати на хід презентації;

- економічна вигода - тиражування презентацій на носії коштує набагато менше за друкування матеріалів;

- багатофункціональність - створена одного разу презентація згодом може застосовуватися в інших умовах і з іншою метою [3].

Хочемо, для прикладу, представити декілька слайдів 3 презентації до теми "Food and Meals", для студентів спеціальності СОА (Середня освіта. Англійська мова і література) з дисципліни “Практичний курс англійської мови”. На вступній частині заняття, для введення студентів в мовне середовище та для мотивації навчальної діяльності, студентам пропонувалося висловити свою точку зору стосовно ситуацій пов'язаних із
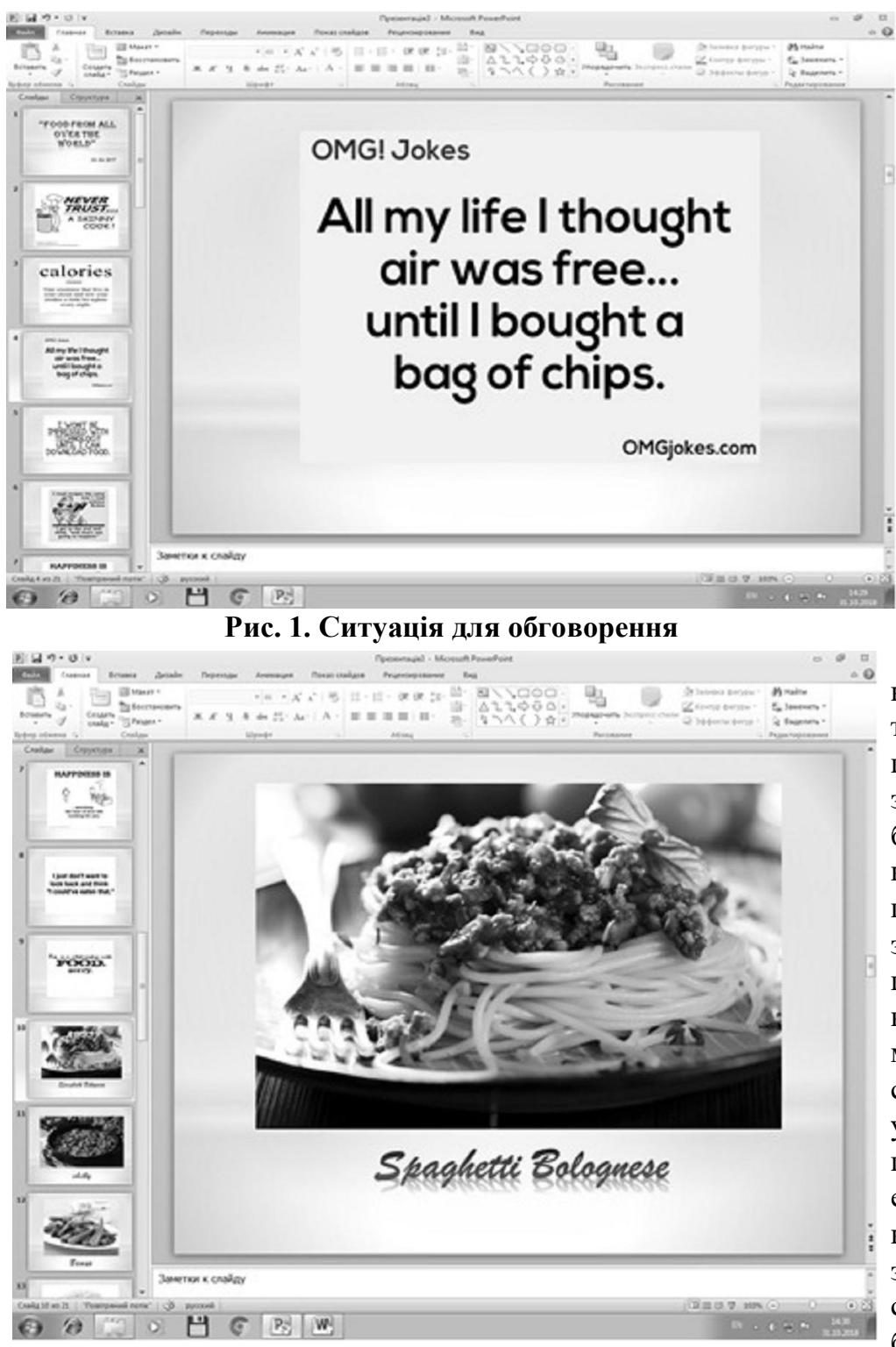

Рис. 2. Зображення всесвітньовідомої страви темою заняття, які були представлені на слайдах Рис. 1.

На основній частині заняття, для розвитку усного мовлення та активізації лексичного матеріалуз теми заняття, студентам пропонувалося відгадати країни за всесвітньо відомими стравами. Скріншот слайда представлено на Рис. 2.

Після виконання вправи на активізацію лексичного матеріалу, студентам пропонувалося знайти та презентувати інформацію про страви за попередньо підготовленим планом (індивідуальна робота в мережі Internet), який було представлено на слайді Рис. 3.

Під час створення слайдів, як зазначає О. Пищик, необхідно врахувати основні вимоги, a саме: слайди мають містити мінімально кількість слів; для заголовків слід використовувати розбірливий шрифт (розмір букв, цифр, знаків, їх контрастність мають бути такими, щоб студентам 3 останніх парт було добре видно презентацію); розміщувати на слайді лише основну інформацію (пропозиції, визначення, слова, терміни, які студенти будуть записувати в зошити, читати уголос тощо, під час демонстрації презентації); заливка фону, букв, ліній має бути спокійного, “неотруйного” кольору, що не буде подразнювати й втомлювати очі студентів, креслення, рисунки, фотографії та інші ілюстраційні матеріали повинні максимально рівномірно заповнювати все екранне поле, бути високої якості, чіткості, контрастності, не слід перевантажувати слайди зоровою інформацією; на перегляд одного слайда слід відводити достатньо часу (не менше 2 - 3 хвилин), щоб студенти могли сконцентрувати увагу на зображенні, простежити послідовність дій, розглянути всі елементи слайда, зафіксувати кінцевий результат, зробити записи в робочі зошити; звуковий супровід слайдів не повинен бути різким, відволікати чи 


\section{ДОЦЛЬНІСТЬ ВИКОРИСТАННЯМУЛЬТИМЕДІЙНИХ ТЕХНОЛОГІЙ}

У ПДГОТОВЦІ МАЙБУТНІХ УЧИТЕЛІВ ІНОЗЕМНИХ МОВ

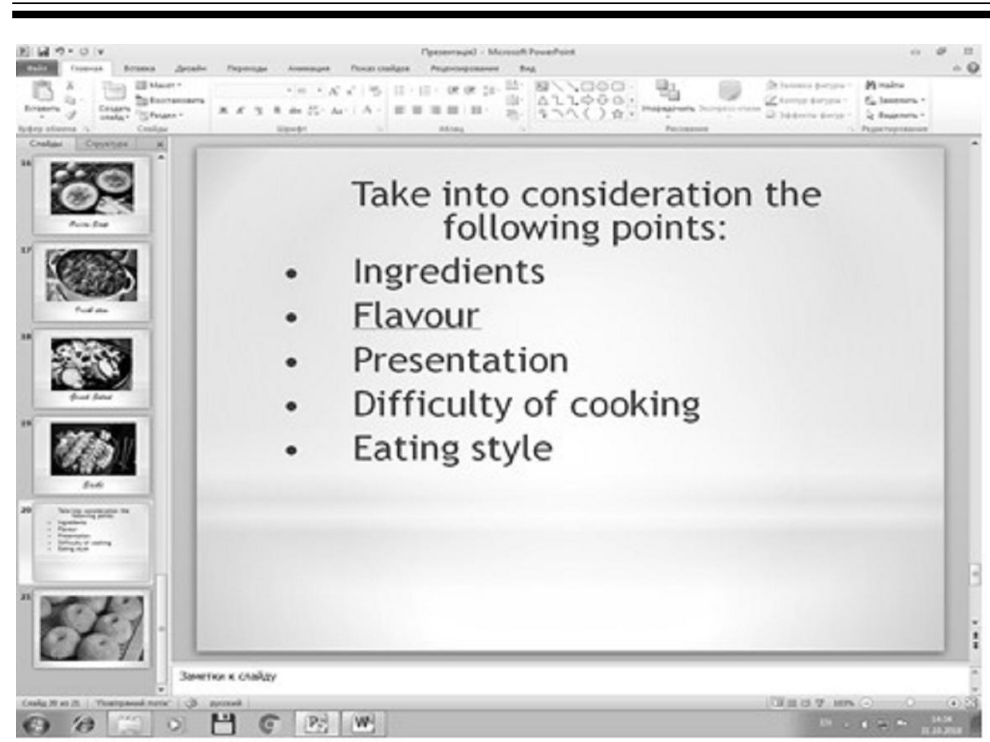

Рис. 3. Вказівки для індивідуальної роботи в мережі

використанням інформаційних технологій як нова форма організації навчального процесу [Електронний ресурс]. - Режим доступу: http://irbis-nbuv.gov.ua/ c gi - bin/irbis n buv/ cgiirbis 64.exe?C21 CO $\mathrm{M}=2 \&$ \& 2 2 1 D $\mathrm{D} \quad \mathrm{N}=$ UJRN\&P2 1 D BN $=$ UJRN \& IMAGE FILE DOWNLOAD= 1 \&Image file name $=$ PDF $/$ Mir_2012_5_37.pdf

3. Гаврілова Н., Хижняк I. Класифікація лекційнихпрезентацій та вимоги до них [Електронний pecypc]. - Режим доступу: http:/ /litmisto.org.ua/?p=19616

4. Годл е в с ька К . В . Особливості використання

дратувати; використання графіки та анімації має робити презентацію привабливішою, акцентувати увагу, а не відволікати від смислового змісту; оформлення презентації має бути унікальним, гармонійним і відповідати загальному стилю, адже від цього залежить переконливість презентації та враження від неї [8].

Висновок. Мультимедійні технології, зокрема презентація є одним з найбільш поширених $\mathrm{i}$ ефективних засобів ілюстрації навчального матеріалу. Проведене дослідження дало змогу зробити висновок, що використання мультимедійних технологій у підготовці майбутніх учителів іноземної мови сприяє інтенсифікації і збагаченню навчального процесу, спонукає до свідомого сприйняття навчального матеріалу, мотивує та активізує навчальну діяльність студентів, індивідуалізує процес навчання іноземної мови, урізноманітнює форми проведення занять, а також сприяє розвитку розумових $\mathrm{i}$ творчих здібностей студентів, підвищує інтерес до навчання та рівень володіння іноземною мовою.

Перспектива подальших досліджень полягає в удосконаленні методичного інструментарію викладача, а саме: методів, прийомів, засобів, форм організації навчальної діяльності студентів в умовах інформаційноосвітнього середовища закладів вищої освіти.

\section{ЛІТЕРАТУРА}

1. Буровицька Ю. М. Інформаційно-комунікаційні технології у вищих навчальних закладах: алгоритм впровадження [Електронний ресурс]. - Режим доступу: http://visnyk.chnpu.edu.ua/?wpfb_dl=3144

2. Василиків I. Навчання маркетингу 3 мультимедіа презентацій у процесі професійної підготовки майбутніх вчителів початкових класів [Електронний ресурс]. - Режим доступу: http:// irbis-nbuv.gov.ua/cgi-bin/irbis nbuv/ cgiirbis 64.exe?C21COM=2\&I21 DBN=UJRN \& P $21 \bar{D}$ B N = U J R N \& I M A G E F I L E DOWNLOAD $=1 \&$ Image file name $=$ PDF $/$ Nzvdpu pp $2013 \quad 40 \quad 46 . p d f$

5. Гужва Т. Використання мультимедійних презентацій на уроках англійської мови [Електронний ресурс]. - Режим доступу: http:// tatyanaguzhva.blogspot.com $/ 2017 / 11 /$ blog-post.html

6. Клачкова М. А. Використання мультимедійних технологій на уроках англійської мови [Електронний pecypc]. - Режим доступу: http://fel2005.dp.ua/ docs $/$ blog/06/040.pdf

7. Комар О. А. Підготовка майбутніх учителів початкової школи до застосування інтерактивних технологій. Теоретико-методичні аспекти: монографія / О. А. Комар. - Умань: РВЦ “Софія”, 2008. - $332 \mathrm{c}$.

8. Пищик О. В. Методика використання мультимедіа-технологій на уроці [Електронний pecypc] / О. В. Пищик // Класному керівнику. Усе для роботи. - Х.: ВГ “Основа”. - №2(50), 2013. Режим доступу: http://schoolplusnet.com/art/ Metodika-vikoristannya-multimeda-tehnologi-na-urots/

9. Токар Л. О. Мультимедійна презентація,як засіб систематизації та узагальнення знань [Електронний ресурс]. - Режим доступу: http:// wiki.soippo.edu.ua/index.php/Мультимедійна _презентація, як_засіб_систематизації _та _узагальнення_знань

\section{REFERENCES}

1. Burovycka, Yu. M. Informacijno-komunikacijni 
texnologiyi u vyshchyp navchalnyh zakladah: algorytm vprovadzhennya [Information and Communication Technologies in Higher Educational Institutions: An Implementation Algorithm]. [Electronic resource]. Access mode: http://visnyk.chnpu.edu.ua/ ?wpfb_dl=3144 [in Ukrainian].

2. Vasylykiv I. Navchannya marketyngu $\mathrm{z}$ vykorystannyam informacijnyh tehnologij yak nova forma organizaciyi navchalnogo procesu [Teaching marketing using information technology as a new form of educational process organization]. [Electronic resource]. Access mode: http://irbis-nbuv.gov.ua/cgibin/irbis nbuv/cgi irbis 64 . exe?C2 $1 \mathrm{COM}=2 \& \mathrm{I} 21 \mathrm{DBN}=\mathrm{UJRN} \& \mathrm{P} 21 \mathrm{D}$ BN=URN\&MAGE FILE DOWNLOAD=1\&Image file name-PDF/ Mir 20125 37.pdf [in Ukrainian].

3. Gavrilova, N. \& Hyzhnyak, I. Klasyfikaciya lekcijnyh prezentacij ta vymogy do nyh [Classification of lecture presentations and requirements to them]. [Electronic resource]. Access mode: http:// litmisto.org.ua/?p=19616 [in Ukrainian].

4. Godlevska, K. V. Osoblyvosti vykorystannya multymedia prezentacij u procesi profesijnoyi pidgotovky majbutnih vchyteliv pochatkovyh klasiv [Features of the use of multimedia presentations in the process of professional training of future primary school teachers]. [Electronic resource]. Access mode: http://irbis-nbuv.gov.ua/cgi-bin/irbis_nbuv/ cgiirbis 64.exe?C21COM=2\&I21DBN=UJRN \&P1DBNUIRN\&MACE FIE DOMNOAD=1\&mge fe namePDF/ Nzvdpu_pp_2013_40_46.pdf [in Ukrainian].
5. Guzhva, T. Vykorystannya multymedijnyh prezentacij na urokah anglijskoyi movy [Use of multimedia presentations in English lessons]. [Electronic resource]. Access mode: http:// tatyanaguzhva.blogspot.com/2017/11/blog-post.html [in Ukrainian].

6. Klachkova, M. A. Vykorystannya multymedijnyh tehnologij na urokah anglijskoyi movy [Use of multimedia technologies in English lessons]. [Electronic resource]. Access mode: http:// fel2005.dp.ua/docs/blog/06/040.pdf [in Ukrainian].

7. Komar, O. A. (2008). Pidgotovka majbutnih uchyteliv pochatkovoyi shkoly do zastosuvannya interaktyvnyh tehnologij. Teoretyko-metodychni aspekty [Training of future primary school teachers to use interactive technologies. Theoretical and methodical aspects]. Uman: RVCz "Sofiya", 332 p. [in Ukrainian].

8. Pyshhyk, O. V. Metodyka vykorystannya multymedia-tehnologij na uroci [Methodology of using multimedia technologies at a lesson]. [Electronic resource]. Access mode: http:// schoolplusnet.com/art/Metodika-vikoristannyamultimeda-tehnologj-na-urots/ [in Ukrainian].

9. Tokar, L. O. Multymedijna prezentaciya yak zasib systematyzaciyitauzagalnennya znan[Multimedia presentation as a mean of knowledge systematization and synthesis]. [Electronic resource] Access mode: http://wiki.soippo.edu.ua/ index.php/Мультимедійна_презентація, як_засіб _систематизації_та_узагальнення_знань [in Ukrainian].

Стаття надійшла до редакції 05.11.2018

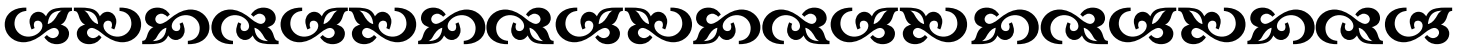

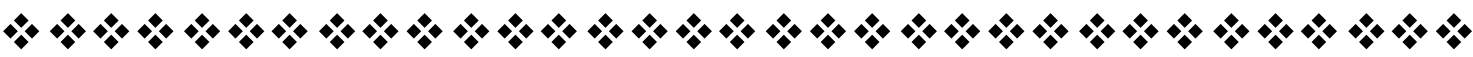

“Розкажи - iя забуду, поқажи - i л пізнаю, дай зробити самому - $і$ я зрозумію”.

Китайське прислів'я

“Відқрити в кожній людині твория, поставити ї̈ на шлях самобутньої творчої, інтелектуально повноқровної праці - ие завдання стає нині першочерговим у прақтичній poбomi".

Василь Сухомлинський украӥнський педагог, публіщист

"Будь-яқе навчання людини, є не що інше, як мистеитво сприяти прагненню природи до свого власного розвитку”.

$\check{\mathscr{Y} о г а н н ~ Т е н р і х ~ Л е с т а л о и и і ~}$ швейцарський педагог

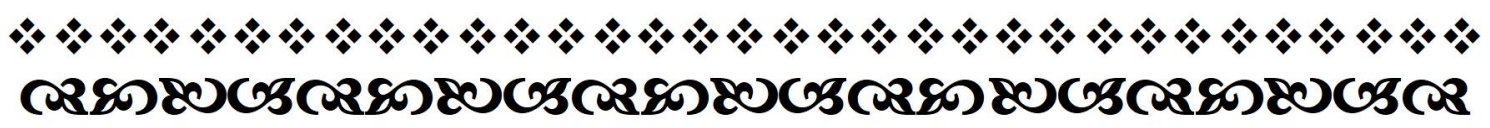

